\title{
THE RELATIONSHIPS AMONG CUSTOMER VALUE, SATISFACTION AND BEHAVIORAL INTENTIONS A General Structural Equation Model
}

\section{Wahyuningsih}

The objective of this paper is to present a comprehensive framework of relationships among customer value, satisfaction, and behavioral intentions. Before testing the model, literature review on the three constructs is presented. From this review, three hypotheses are proposed and tested in this study: (1) Customer value is antecedent to customer satisfaction, (2) Customer value has a direct link to behavioral intentions, and (3) The relationship between customer value and behavioral intentions is mediated by customer satisfaction. Structural Equation Modeling using AMOS 5 was employed to test the model. The result suggests that the relationship between customer value and behavioral intentions is mediated by customer satisfaction.

Keywords: behavioral intentions; customer value; satisfaction 
Gadjah Mada International Journal of Business, September-December 2005, Vol. 7, No. 3

\section{Introduction}

In recent years, there has been a contentious issue concerning the relationships among customer value, customer satisfaction, and behavioral intentions. Some scholars (e.g. Bolton and Drew 1991; Petrick et al. 2001) argue that customer value is a higher order concept and incorporates more stable judgment than customer satisfaction. Therefore, the relationship between the two constructs can be seen as: customer satisfaction affects customer value. In contrast, some scholars (e.g. Choi et al. 2004; Cronin et al. 2000; Fornell et al. 1996; Lam et al. 2004; McDougall and Levesque 2000; Patterson and Spreng 1997; Yang and Peterson 2004) argue that satisfaction is a better predictor for future behaviors and value acts as an antecedent to satisfaction judgments. Thus, the relationship between the two constructs can be seen as: customer value affects customer satisfaction. In addition, arguments also persist surrounding the outcomes of customer value. According to some scholars (e.g. Chang and Wildt 1994; Cronin et al. 1997; Hartline and Jones 1996) there is a direct link between customer value and be-havioral intentions without the mediating role of satisfaction. Thus, the role of satisfaction in identifying the future behavioral intentions is not significant. In contrast, scholars such as Fornell et al. (1996), Lametal. (2004), and Patterson and Spreng (1997) argue that the link between customer value and behav- ioral intentions is mediated by satisfaction. These varying arguments indicate that the relationships among customer value, customer satisfaction, and behavioral intentions have not yet been clearly defined. Thus, there is a need to closely investigate the relationships among these three constructs in more depth.

\section{Conceptual Background}

\section{Customer Value}

The concept of customer value has become of keen interest to academics and practitioners alike. This is because value has been considered as an essential element of an organi-zation's competitive strategy (Gale 1994) and, thus, plays a crucial role at the heart of marketing activity (Holbrook 1999). Organizations which have a strong focus upon customer value will form a sustainable com-petitive advantage (Porter 1985; Parasuraman 1997; Woodruff 1997; Slater and Narver 2000). The rationale behind this is that, delivering better value to customers might result in a likelihood of purchase, repeat purchase, and positive word-ofmouth communication (Bolton and Drew 1991; Grisaffe and Kumar 1998). In other words, if the organizations know what drives value for its customers and provides superior customer value, they have a greater probability of obtaining and retaining customers (Gabbott 2004). Therefore, it can be noticed that in-depth understanding of 
Wahyuningsih-The Relationships among Customer Value, Satisfaction, and...

customer value is very important for companies to succeed.

Despite this importance, the literature suggests that the study of customer value is in its infancy (Flint et al. 2002). Even the term "customer value" can be confusing (Flint et al. 2002), multifaceted, and complicated (Huber et al. 2001). Value means many things to many people (Weinstein 1998). Therefore, the concept of value needs to be defined clearly including the identification of the components.

In this study, customer value is defined as "a difference between total benefits and total sacrifices perceived by consumers in purchasing a product or service." Total benefits are a combination of physical attributes, service attributes, and technical support available in relation to a particular use situation (Monroe 1990). Meanwhile, sacrifices are what the consumers have to give up in obtaining the purchased products. These are defined from the customer's perspective (Monroe 1990) and include monetary terms (Anderson et al. 1993) and non-monetary terms such as energy, time and effort (Cronin et al. 1997). Within the identification of benefits and sacrifices, consumers not only consider the performance or functional matters but also social and emotional factors (Sheth et al. 1991; Sheth et al. 1999; Sweeney and Soutar 2001). Therefore, the investigation of customer value covers functional value, social value, and emotional value.

Functional value is defined as the perceived utility acquired from an alternative's capacity for functional, utilitarian, or physical performance (Sheth et al. 1991). In other words, it is the quality of physical outcome of using the product or service, which refers to how well a product or service serves its principal physical function consistently (Sheth et al. 1999). Functional value is related to economic utility, the benefits associated with pos-sessing the product or service, and un-derlies the performance of the object on a series of salient attributes such as price, reliability, and durability.

Social value is the perceived utility acquired through the consumption of an alternative as a result of its association with one or more specific social groups (Sheth et al. 1991). Alternatives acquire social value through association with positively or negatively stereotyped demographic, socioeconomic, and cultural-ethnic groups (Sheth et al. 1991). In other words, social value is the utility derived from the product's ability to enhance social self-concept (Sweeneyand Soutar 2001; Wang et al. 2004). Consumers choose the products that convey an image congruent with the norms of their friends and associates, or that convey the social image they wish to project (Sheth et al. 1999).

Emotional value is the economic value or monetary worth of feelings when customers experience an organization's products and/or services (Barlow and Maul 2000). It further refers to the feelings that customers experience or anticipate experiencing 
Gadjah Mada International Journal of Business, September-December 2005, Vol. 7, No. 3

when they deal with organizations and their representatives (Barlow and Maul 2000). Likewise, Sheth et al. (1991) in agreement with Wang et al. (2004) define emotional value as the perceived utility acquired by consuming an alternative as a result of its ability to arouse feelings or affective states. They maintain that many products are associated with or facilitate the arousal of specific emotions or feelings; for example, comfort, security, excitement, romance, passion, anger, fear, and guilt. Therefore, to analyze how customers value a product, it is important to take these emotions into account.

\section{Customer Satisfaction}

There has been extensive research into customer satisfaction for many years. This is because customer satisfaction has been considered by companies as a key strategy to gain competitive advantage (Woodruff and Gardial 1996).

Along with the research into customer satisfaction, there has been an increase in the diversity of the definitions of customer satisfaction in the literature. From a review of the literature, there are four main determinants that have been used to define and measure customer satisfaction. They are performance, quality, expectation, and disconfirmation. Researchers have used combinations of these constructs differently for measuring customer satisfaction. The combinations are: expectation and disconfirmation (e.g. Oliver 1980), expectation and performance (e.g. Fornell 1992; Johnsonet al. 1995), qualityand disconfirmation (e.g. Anderson and Sullivan 1993), expectation, performance, and dis-confirmation (e.g. Churchill and Surprenant 1982; Woodruff et al. 1983; Wirtz and Bateson 1999; McQuitty et al. 2000), expectation and quality (Giese and Cote 2002).

In this study, the definition put forward by Fornell (1992, pp. 11) is adopted, which argue that customer satisfaction is "An overall post-purchase evaluation." This definition focuses on post-purchase perceived product performance compared with prepurchase expectations.

\section{Behavioral Intentions}

This research investigates two behavioral intentions. They are repurchase intentions and word-of-mouth communication. The discussion concerning the two concepts is presented below:

Repurchase Intentions. Since behavioral intentions are easier to measure than actual behavior, there are numerous studies of repurchase intentions (Bolton et al. 2000). However, these studies must be interpreted with caution because behavioral intentions are subject to criticism since intentions do not always lead to actual behavior (e.g. Gabler and Jones 2000; Morwitz and Schmittlein 1992).

Repurchase intentions are defined as "the individual's judgment about buying again a designated service from the same company, taking into account his or her current situation and likely circumstances" (Hellier 2003: 1764). From this definition, it is clear that 
Wahyuningsih-The Relationships among Customer Value, Satisfaction, and...

repurchase behavior occurs when customers purchase other products or services for the second or more times with the same company; and the reason for purchasing again is mainly triggered by customer experience towards the products or services.

Theory suggests that increasing customer retention is a key act of the ability of a company to generate profits (Zeithaml et al. 1996). This is because the longer consumers stay with a company, the more products or services they buy from the company and no excess marketing outlay to win new customers. To retain customers, a company needs to improve its service quality, which in turn leads to high service value (Cronin et al. 2000). Thus, it is noticed that consumers are more likely to purchase again from the same company if they think that what they have received was worthier than what they have given up.

Word-of-Mouth Communication (WoM). WoM communication is defined as "informal communications directed at other consumers about the ownership, usage, or characteristics of particular goods and services and/or their sellers" (Westbrook 1987: 261). Thereasons for customers doing WoM communications are because they want to ease a tension that the positive or negative experience produced, to reassure themselves in front of others, to gain support from others who share their opinions, to gain attention or to share the benefits of things enjoyed (Wirtz and Chew 2002).
WoM has been identified in previous research as an important behavior after consuming a product or service (e.g. Gremler et al. 2001; Wirtz and Chew 2002). This is primarily because WoM communication provides faceto-face, often vivid information that is highly credible (Spreng et al. 1995). In addition, consumers frequently rely on informal and/or personal communications sources in making purchase decisions as opposed to more formal and/or organizational sources such as advertising campaigns (Bansal and Voyer 2000). Furthermore, WoM has been widely acknowledged as an informal communication source between consumers that has great economic impact (Murray 1991). Customers who show up on the strength of a personal recommendation tend to be more profitable and stay with the company longer than customers who respond to conquest advertising, sales pitches, or price promotions (Reichheld 1996). From the previous studies, it is perceived that WoM plays a key role in shaping consumers attitudes and behaviors (Harrison-Walker 2001). Thus, WoM serves as enforcement to consumers to remain loyal to a service provider.

WoM is more important and influential within a service context than strictly just product marketing scenarios, given their intangibility and higher associated risk (Mangold and Brockway 1999). Compared to purchasers of goods, Murray (1991) found that service buyers have greater confidence in personal sources of informa- 
tion as well as a greater pre-purchase preference for personal information sources. In addition, Ennew et al. (2000) suggest that WoM may also be one of the most powerful form of communication within financial services, given they tend to be characterized by a predominance of experience and credence qualities. A consumer may not understand a service fully before its consumption; he or she might seek WoM information froman experienced source (Bansal and Voyer 2000). Therefore, WoM becomes especially important within the services purchase decision context.

\section{The Relationship between Customer Value and Customer Satisfaction}

From the literature, several studies have provided empirical evidence of the link between value and satisfaction (e.g. Cronin et al. 2000; Eggert and Ulaga 2002; Fornell et al. 1996; McDougall and Levesque 2000; Patterson and Spreng 1997; Wang et al. 2004). The proposed relationship of perceived value upon customer satisfaction is supported by value disconfirmation experience (Hellier et al. 2003). The authors point out that, "when a single purchase of a productor service is made, the customer expects to receive value. If anything happens after purchase that unexpectedly reduces or increases the cost incurred or benefit received, the perceived value is altered. The customer becomes less or moresatisfied, which in turn influences subsequent customer value expectations, purchase behavior, and overall customer satisfaction" (Hellier et al. 2003: 1772).

Moreover, Naumann and Giel (1995) argue that the concept of value is closely linked to customer satisfaction. Their study examines whether overall customer satisfaction is determined by the degree to which customer expectations are met. If a cus-tomer's expectations towards components of value are exceeded, high levels of customer satisfaction will be achieved; if a customer's expectations are not met, customer dissatisfaction will result. The authors conclude that customer satisfaction is the best "scorecard" for measuring delivered customer value. This is supported by Jones and Sasser (1995) who assert that providing customers with outstanding value may be the only reliable way to achieve sustained customer satisfaction. The positive relationship between value and satisfaction is also supported by the argument that:

"in situations where a particular company service consists of multiple options, customers do not simply consume value. In a relationship with the service provider, customers select options and create value for themselves and, thus, increase their product or service satisfaction (Hellier et al. 2003: 1772).

This argument is in line with Caruana et al. (2000) who suggest that the effect of quality on satisfaction is not just direct but is also moderated by value. From these arguments it is clear 
Wahyuningsih-The Relationships among Customer Value, Satisfaction, and...

Table 1. The Difference between Customer Value and Customer Satisfaction

\begin{tabular}{|c|c|c|}
\hline Customer Value & Customer Satisfaction & Sources \\
\hline $\begin{array}{l}\text { - Cognitive construct } \\
\text { - Pre-/post-purchase perspective } \\
\text { - Strategic orientation } \\
\text { - Present and potential customers } \\
\text { - Suppliers' and competitors } \\
\text { offerings }\end{array}$ & $\begin{array}{l}\text { - Affective construct } \\
\text { - Post-purchase perspective } \\
\text { - Tactical orientation } \\
\text { - Present customers } \\
\text { - Suppliers' offerings }\end{array}$ & Eggert and Ulaga (2002) \\
\hline $\begin{array}{l}\text { Can be generated without the } \\
\text { product or service being bought } \\
\text { or used }\end{array}$ & $\begin{array}{l}\text { Depends on experience of } \\
\text { having used the product or } \\
\text { service }\end{array}$ & $\begin{array}{l}\text { Sweeney and } \\
\text { Soutar (2001) }\end{array}$ \\
\hline
\end{tabular}

that there is positive link between customer value and satisfaction.

From the review above, it is important to point out the difference between customer value and satisfaction. The summary can be seen in Table 1 .

It is interesting to note that there are two arguments concerning the causal relationship between customer value and satisfaction. First, the scholars who favor the satisfaction and value causal link(e.g. Bolton and Drew 1991; Petrick et al. 2001) argue that customer value is a higher order concept and has more stable judgment than satisfaction, and hence acts as a consequence of post purchase evaluation constructs. Second, the scholars who favor the value and satisfaction causal link (e.g. Brady and Cronin 2001; Cronin et al. 2000; Eggert and Ulaga 2002; Fornell et al. 1996; Lam et al. 2004; McDougall and Levesque 2000; Patterson and Spreng 1997) argue that satisfaction is a better predictor for future behaviors and value acts as an antecedent to satisfaction judgments.
Woodruffand Gardial (1996) support the "value and satisfaction" causal link arguing that customer value describes the nature of the relationship among the organization, customer, and the service, while customer satisfaction represents a customer's reaction to the value received from a particular product offering. This is in agreement with Jones and Sasser (1995) who support this view that providing customers with good value may be the only reliable way to achieve sustained customer satisfaction.

This study adopts the "value and satisfaction" causal link. The rationale behind this argument is that:

Customervalue is identified in thelevel of "buy or not to buy a product" (e.g. Holbrook 1999), meanwhile satisfaction is a judgment made by consumers after buying a product (e.g. Woodruff and Gardial 1996; Sweeney and Soutar 2001).

Therefore, the decision to buy (or not to buy) the product occurs before consumers demonstrate an expression 
Gadjah Mada International Journal of Business, September-December 2005, Vol. 7, No. 3

of their feelings. Theoretically, customer value can be considered as a cognition-based construct capturing any benefit-sacrifice discrepancy, whereas customer satisfaction is primarily an affective and evaluative response (Eggert and Ulaga 2002; Lam et al. 2004; Oliver 1993). The social science literature maintains that cognitive thought processes trigger affective responses (Weiner 1986), suggesting that customer value judgments affect perceptions of satisfaction (Lam et al. 2004). Thus, customer value is placed before customer satisfaction.

Hypothesis 1: Customer value is antecedent to customer satisfaction
The Relationship between

Customer Value and Behavioral Intentions (Direct Impact Model)

Most conceptual and empirical contributions to value literature conceive a direct impact of customer value on behavioral outcomes neglecting the role of satisfaction (Eggert and Ulaga 2002). For example, Grisaffe and Kumar (1998) point out two behavioral intentions as direct consequences of customer value. These are customer likelihood to recommend and likelihood to continue doing business with the company. This is in agreement with the Petrick's (2002) argument that customer value has a direct impact on

Figure 1. A Direct Link between Value and Purchase Intentions

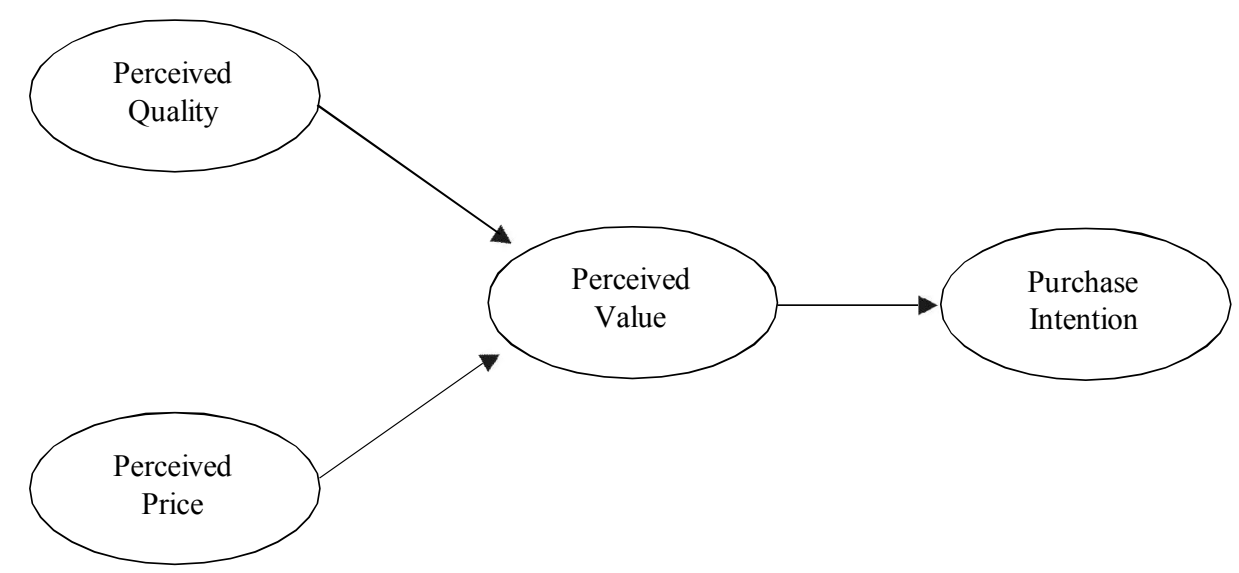

Source: Adapted from Chang and Wildt (1994) 
Wahyuningsih-The Relationships among Customer Value, Satisfaction, and...

repurchase intentions and word-ofmouth communication. In addition, Bolton and Drew (1991) found that value is related to customers' subscription intentions and intentions to recommend. This is in line with Hartline and Jones (1996) who suggest that value leads to the increase of word-of-mouth intentions. Moreover, Chang and Wildt (1994) found that perceived value mediates the relationship between perceived quality, perceived price, and purchase intention. The model of these relationships can be seen in Figure 1.

Further to the above discussion, Cronin et al. (1997) propose the value added model that examines service quality and sacrifice as a direct measure of value that has a direct link to purchase intentions. They found that the addition of a direct measure of service value to the model which is defined solely by service quality and sacrifice increases the ability of the model to explain variance in consumers' purchase intentions.

Basically, a rationale for neglecting satisfaction is provided by Gross (1997) who argues that in business markets, purchasing managers' decision making is mainly guided by cognitive factors and not by affective ones. Therefore, a direct link between value and outcome variables has been developed taking into consideration solely the cognitive input and cognitive output which consist of repurchase intentions, search for alternatives, and word- of-mouth communication (Eggert and Ulaga 2002). In consumer markets, buying decision-making is determined by both cognitive and affective factors (Sheth et al. 1991). Hence, it is reasonable to argue that there is a direct relationship between value and behavioral intentions in consumer markets since value involves emotional aspects in which, according to most of the literature, can only be captured in the study of customer satisfaction. In this context, customer value is supposed to have a direct impact on behavioral intentions.

Grewal et al. (1998) and Sweeney et al. (1999) suggest that in a prepurchase situation, perception of value might directly influence willingness to buy. Neal (1999) argues that satisfaction is necessary, but value drives loyalty. This is because the most satisfied customer may not necessarily be the most loyal; thus, value is a better predictor for loyalty. The key foundation underlying all these studies is that value is the key linkage between the cognitive elements of perceived quality or performance, perceived sacrifice, and behavioral intentions (Patterson and Spreng 1997). Based on these previous studies, it is noticed that value may well directly impact on behavioral intentions. Based on this discussion, it is hypothesized that:

Hypothesis 2: Customer value has a directlink to behavioral intentions. 
Gadjah Mada International Journal of Business, September-December 2005, Vol. 7, No. 3

The Relationship between

Customer Value and Behavioral

Intentions is Mediated by

Customer Satisfaction (Indirect

Impact Model)

Unlike studies that have found perceived value to influence intentions directly thus neglecting satisfaction, the findings of Patterson and Spreng (1997) suggest that value is completely mediated through satisfaction in influencing repeat purchase behavior. Their argument supports an earlier study by Fornell et al. (1996) that the impact of value on behavioral intentions is mediated by satisfaction. In agreement with this view, McDougall and Levesque (2000) investigate the relationships among these constructs: core service quality, relational service quality, perceived value, customer satisfaction, and behavioral intentions to purchase across four services. They found that core service quality and perceived value are the most important drivers of customer satisfaction with relational service quality a significant but less important driver. They also reveal that there is a direct link between customer satisfactionand behavioral intentions. The links can be seen in the following Figure 2 .

This argument is in agreement with the work of Chan et al. (2003), Cronin et al. (2000), McNaughton et al. (2002) and Petrick et al. (2001) who assess the effects of value on behavioral intentions through customer satisfaction. In addition, Lam et al. (2004) found that customer satisfaction mediates the relationship between customer value and customer loyalty including repurchase intentions and intentions to recommend. From these previous studies, it is clear that the relationship between perceived value and behavioral intentions is mediated by customer satisfaction.

Figure 2. Indirect Link between Perceived Value and Behavioral Intentions

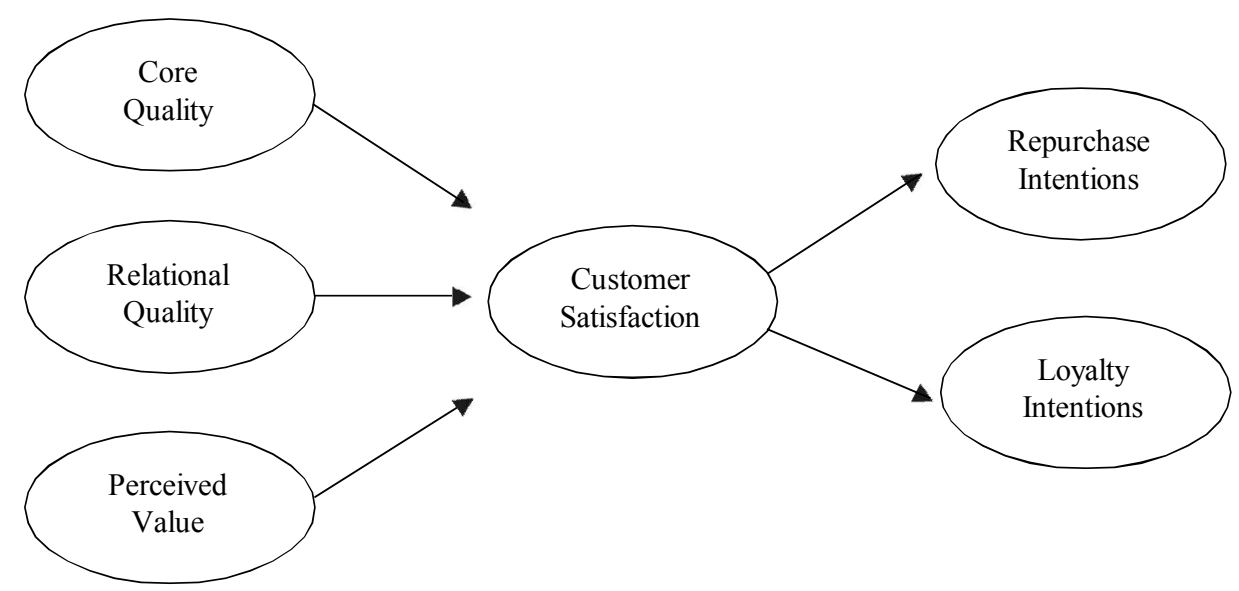

Source: McDougall and Levesque (2000) 
Wahyuningsih-The Relationships among Customer Value, Satisfaction, and...

The reasoning behind the argument that the link between value and behavioral intentions is mediated by satisfaction may be described as follows. To continue doing business with a company and recommend to other peopleabout the products and services, consumers need to have formed a judgment towards the products and services as to whether they are satisfied or dissatisfied. It might be difficult for a consumer to form behavioral intentions before they have a reaction (or judgment) towards the products and services. Thus, the degree of behavioral intentions is dependent on the level of satisfaction. Therefore, it can be noticed that the link between customer value and behavioral intentions may also be mediated through customer satisfaction. Hence, it is hypothesized that:

Hypothesis 3: The relationship between customer value and behavioral intentions is mediated bycustomer satisfaction.

\section{Methodology}

This research investigates the customer value-satisfaction-behavioral intentions model displayed by each consumer type regarding their experiences with the insurance industry. To collect these data, closed-ended questions in a structured questionnaire was employed. A nine point Likert scale ${ }^{1}$ from "1" to "9" was used to capture the behavior, attitudes, and perceptions of consumers toward the product. The unit of analysis of this study are individuals, specifically, students who have purchased car insurance within the past year in Melbourne, Australia. A convenience sample of 654 questionnaires were distributed directly to respondents. Out of 654 questionnaires, 546 questionnaires were usable and 13 questionnaires were incomplete. Thus, the response rate in this survey was 85 percent.

\section{Data Analysis}

Data analysis techniques used in this research are Structural Equation Modeling (SEM). The assumptions to apply these techniques including absence of multicollinearity, outliers, and heteroscedasticity, as well as the presence of homogeneity, linearity, and normality have been met. SEM was employed to construct and test the measurement model, which enables a comprehensive, confirmatory assessment of construct validity, and provides a confirmatory assessment of convergent validity and discriminant validity (Anderson and Gerbing 1988).

\footnotetext{
${ }^{1}$ A nine point Likert scale from 1="very low" to 9="very high" was used in the questionnaire as suggested by Zikmund (1994: 371).
} 
Gadjah Mada International Journal of Business, September-December 2005, Vol. 7, No. 3

\section{Results}

Results from testing the hypotheses using structural equation modeling are presented in Figure 3, Table 2, Table 3, and Table 4.

The result on Table 2 shows that the model $\chi^{2}$ is 53.247 with degree of freedom 20 . Thus the likelihood-ratio chi-square $\left(\chi^{2} / d f\right)$ is $2.662 . \chi^{2} / d f$ ratios of less than 3 have been interpreted as indicating a good fit to the data. Hence, the $\chi^{2} / d f$ ratio of 2.662 from the model indicates a good fit.
Table 2. Summary of Model Fit

\begin{tabular}{lrr}
\hline Model Fit Assessment & & Result \\
\cline { 1 - 1 }$\chi^{2}$ & 53.247 \\
Degree of freedom & & 20 \\
P-value & .000 \\
$\chi^{2} / d f$ & & 2.662 \\
GFI & .976 \\
AGFI & .950 \\
RMSEA & .063 \\
\hline
\end{tabular}

Figure 3. Structural Model with Standardized Coefficient Estimates

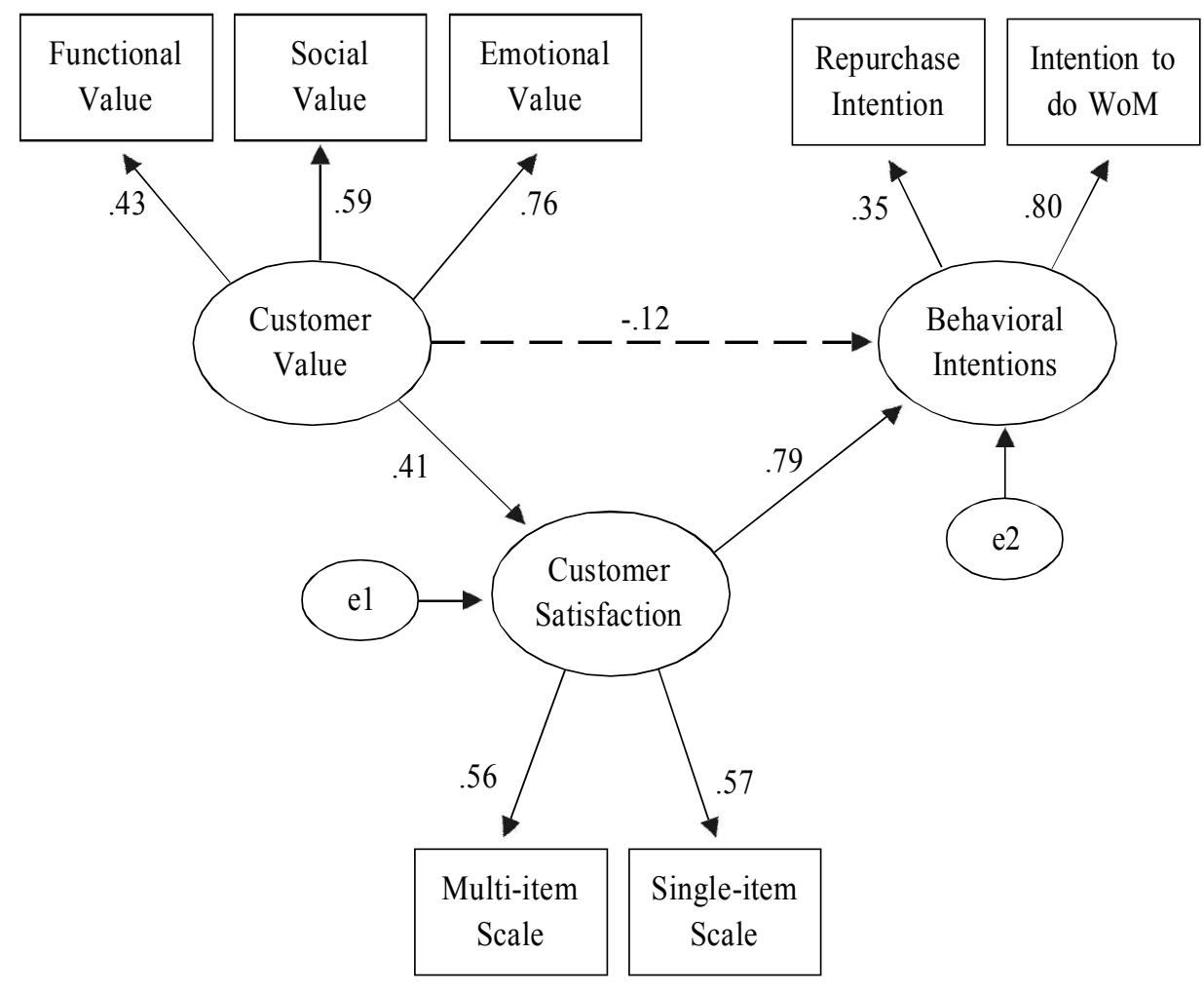

Notes: $-\longrightarrow \rightarrow$ The relationship is not significant 
Wahyuningsih-The Relationships among Customer Value, Satisfaction, and...

The Goodness-of-Fit Index (GFI) is a measure of the relative amount of variance and covariance between variables that are predicted by sample size (Bollen 1989). The AGFI differs from the GFI only in the fact that it adjusts for the number of degrees of freedom in the specified model (Byrne 1998). Although both indexes range from zero to 1.00 , with values close to 1.00 being indicative of good fit, and 1.00 indicating a perfect fit (Arbuckle 1999). Based on the GFI and AGFI reported in Table 2 (.976 and .950, respectively), it confirms that the hypothesized model fits the sample data fairly well.

Root Mean-Square Error of Approximation (RMSEA) takes into account the error of approximation in the population and asks the question, "How well would the model, with unknown but optimally chosen parameter values, fit the population covariance matrix if it were available (Byrne 1998: 84). A value about 0.08 or less for the RMSEA would indicate a reasonable error of approximation(Arbuckle 1999; Browne and Cudeck 1993). Thus, a value of .063 for the RMSEA shows that the model performs well.

Having a good model fit, as indicated above, it is then necessary to identify the direct, indirect, and total effects among value, satisfaction, and behavioral intentions. Direct effects are the influences of one variable on another that are not mediated by any other variable, while indirect effects are ones

Table 3. Covariance Matrices of Direct, Indirect, and Total Effect

\begin{tabular}{|c|c|c|c|c|c|c|}
\hline & \multicolumn{2}{|c|}{ Direct Effect } & \multicolumn{2}{|c|}{ Indirect Effect } & \multicolumn{2}{|c|}{ Total Effect } \\
\hline & $\begin{array}{l}\text { Customer } \\
\text { Value }\end{array}$ & $\begin{array}{c}\text { Customer } \\
\text { Satisfaction }\end{array}$ & $\begin{array}{l}\text { Customer } \\
\text { Value }\end{array}$ & $\begin{array}{c}\text { Customer } \\
\text { Satisfaction }\end{array}$ & $\begin{array}{l}\text { Customer } \\
\text { Value }\end{array}$ & $\begin{array}{c}\text { Customer } \\
\text { Satisfaction }\end{array}$ \\
\hline $\begin{array}{l}\text { Customer } \\
\text { Satisfaction }\end{array}$ & .41 & .00 & .00 & .00 & .41 & .000 \\
\hline $\begin{array}{l}\text { Behavioral } \\
\text { Intentions }\end{array}$ & -.12 & .79 & .32 & .00 & .20 & .79 \\
\hline
\end{tabular}

Figure 4. The Relationships among Customer Value, Customer Satisfaction, and Behavioral Intentions

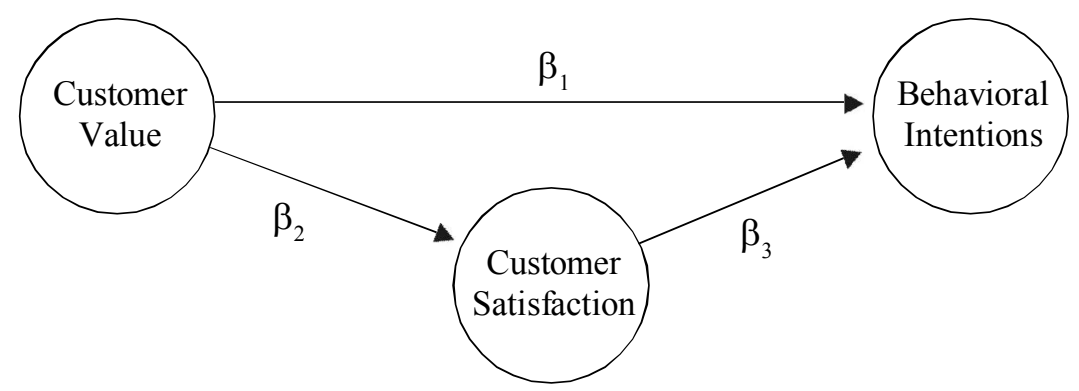


Gadjah Mada International Journal of Business, September-December 2005, Vol. 7, No. 3

that are mediated by at least one other variable, and the total effects are the sum of directand indirect effects (Bollen 1989: 376). Figure 4 shows that the direct effects investigated in this study are customer value on behavioral intentions $\left(\beta_{1}\right)$, customer value on customer satisfaction $\left(\beta_{2}\right)$; and customer satisfaction on behavioral intentions $\left(\beta_{3}\right)$. The indirect effect of customer value on behavioral intention is $\beta_{2} \beta_{3}$. The total effect of customer value on behavioral intentions is $\left(\beta_{1}+\beta_{2} \beta_{3}\right)$. Results of testing the direct, indirect, and total effects are reported in Table 3.

Results of testing the direct and indirect effect using SEM shows that the indirect effect of customer value on behavioral intentions is stronger (.32) than the direct effect (-.12). This result indicates that the link between customer value and behavioral intentions is indirect; in other words, it is mediated by customer satisfaction. The total effect of customer satisfaction on behavioral intentions is stronger (.79) than the total effect of customer value on behavioral intentions (.20). Thus, therelationship between customer value and behavioral intentions is mediated by satisfaction. To confirm this result, regression weights from AMOS 5 are listed on Table 4.

Results from theregression weights above indicate that the effect of customer value on behavioral intentions is not significant $(\mathrm{p}=.162)$. Meanwhile, the effect of customer value on satisfaction and the effect of satisfaction on behavioral intentions are both significant at the 0.001 level. Therefore, it confirms that the relationship between customer value and behavioral intentions is mediated by customer satisfaction.

\section{Discussion}

This study agrees with previous studies (e.g. Chan et al. 2003; Fornell et al. 1996; Jones and Sasser 1995; Choi et al. 2004; Hellier et al. 2003; Wang et al. 2004; Yang and Peterson 2004), which point out the positive link between customer value and satisfac-

Table 4. Regression Weights

\begin{tabular}{|c|c|c|c|c|c|c|}
\hline & & & Estimate & S.E. & C.R. & Sig. \\
\hline Customer Value & $\rightarrow$ & Customer Satisfaction & .233 & .051 & 4.560 & .000 \\
\hline Customer Value & $\rightarrow$ & Behavioral Intentions & -.022 & .016 & -1.399 & .162 \\
\hline Customer Satisfaction & $\rightarrow$ & Behavioral Intentions & .257 & .053 & 4.852 & .000 \\
\hline Behavioral Intentions & $\rightarrow$ & Intention to do WoM & 4.878 & .708 & 6.886 & .000 \\
\hline Customer Value & $\rightarrow$ & Social Value & 1.999 & .279 & 7.174 & .000 \\
\hline Customer Value & $\rightarrow$ & Emotional Value & 2.872 & .443 & 6.476 & .000 \\
\hline Customer Satisfaction & $\rightarrow$ & Single-item Scale & 1.080 & .139 & 7.764 & .000 \\
\hline
\end{tabular}


Wahyuningsih-The Relationships among Customer Value, Satisfaction, and...

tion. At the conceptual level, this study proposes that value come first before satisfaction. The link between value and satisfaction was then tested empirically using structural equation modelling. The result confirms that value should be placed before satisfaction. Thus the link should go from value to satisfaction, not in the opposite direction.

Therefore, the result of this research contradicts previous studies which maintain that the link should go from satisfaction to value (e.g. Bolton and Drew 1991; Petrick et al. 2001). According to Petrick et al. (2001), satisfaction and past behavior are antecedents to perceived value in the prediction of intentions torepurchase. Similarly, Bolton and Drew (1991) argue that customer satisfaction and service quality are antecedents to service value.

The arguments behind the causal link from satisfaction to value according to these scholars may be because consumers have already had prior experiences with the product. In the study by Petrick et al. (2001), consumers had prior experiences of vacation places they visited, and in Bolton and Drew's (1991) study, consumers had enough experiences toward the use of home telephone. Therefore, the consumers have had judgment or evaluation towards the product (Day 1984; Westbrook and Oliver 1991) based on a series of consumer product interactions (Yi 1990). This judgment whether the consumers are satisfied or not will have an impact on how they perceive the value of the product. Thus, perceived value is dependent upon the consumer's level of satisfaction gained from their experiences using the product. However, this argument may not be applied to consumers who buy a product for the first time (first-buyers) who do not have any prior experience of the product. In other words, firstbuyers do not have judgment or evaluation whether they satisfied or not. As a consequence, they will not be able to value the product based on their level of satisfaction. Hence, the "satisfaction $\rightarrow$ value" model cannot be applied for first-buyers. This is due to the fact that to apply this model, consumers need to have experience or judgment toward the product before they perceive the value of the product. Thus, the "satisfaction $\rightarrow$ value" model has limitation on the frequency of the product being purchased by consumers.

On the other hand, the "value $\rightarrow$ satisfaction" model can be applied more generally for first-buyers as well as for consumers who have purchased the product many times. This is because customer value can be generated without the product or service being bought or used (Sweeney and Soutar 2001). In other words, customer value can be identified from a pre- or post-purchase perspective (Eggert and Ulaga 2002). Meanwhile, satisfaction depends on experience of having used the product or service (Sweeney and Soutar 2001), hence it can only be identified from post-purchase perspective (Eggert and Ulaga 2002). Therefore, value is an 
Gadjah Mada International Journal of Business, September-December 2005, Vol. 7, No. 3

antecedent of satisfaction which confirms the "value $\rightarrow$ satisfaction" model.

Finally, in this study, the positive link from customer value to customer satisfaction has been developed at the theoretical level and tested empirically. Theoretically, customer value can be considered as a cognition-based construct capturing any benefit-sacrifice discrepancy, whereas customer satisfaction is primarily an affective and evaluative response (Oliver 1993; Eggert and Ulaga 2002; Lam et al. 2004). The social science literature maintains that cognitive thought processes trigger affective responses (Weiner 1986), suggesting that customer value judgments affect perceptions of satisfaction (Lam et al. 2004). Perceived value is the consequence of a mental weighing of perceived benefits versus sacrifices, whereas satisfaction is an affective response to service evaluation (Choi et al. 2004). Thus, value should be placed before satisfaction in the model because value is an antecedent to satisfaction ("value $\rightarrow$ satisfaction").

This study agrees with previous studies (e.g. Chan et al. 2003; Eggert and Ulaga 2002; Fornell et al. 1996; Lam et al. 2004; McNaughton et al. 2002; Patterson and Spreng 1997; Wang et al. 2004), which argue that the relationship between customer value and behavioral intentions is mediated by satisfaction. This study has confirmed that, there is a positive relationship between customer value and customer satisfaction, and a positive relationship between customer value and behavioral intentions. However, when satisfaction was included in the model, the direct link between customer value and behavioral intentions became nonsignificant (see Figure 3). This suggests that satisfaction mediates the relationship between customer value and behavioral intentions.

To some extent, this result is different from that of Choi et al.'s (2004) who investigated the relationships among quality, value, satisfaction, and behavioral intentions in health care industry. Their finding, which suggests a positive relationship between customer value and satisfaction, and between satisfaction and behavioral intentions, is in agreement with this present study. The one difference is that when satisfaction is included in the model (Choi et al.'s model) the relationship between customer value and behavioral intentions is seen to be both positive and significant. However, in the present study, the relationship between customer value and behavioral intentions becomes non-significant when satisfaction is included in the model. The reasons behind this difference may be that Choi et al.(2004: 917) undertook their study when consumers were still in hospital waiting for medication after being examined by physicians which indicates that the consumers were still in the process of receiving the service. In contrast, this study was conducted after consumers made transactions: the purchase or renewal of their car insurance.

From the above, it is interesting to note that customer perceived value is 
Wahyuningsih-The Relationships among Customer Value, Satisfaction, and...

affected by the duration between time of purchase and consumers being asked about their perceived value of the purchased product. This argument is supported by the results of testing the relationship between value perceived by consumer and sacrifice across different time of payment/transaction.

This finding creates an alert that perceived value is affected by the time of transaction. When consumers are asked to provide information about their perception of value toward a certain product or service right after the transaction, they will feel that the sacrifices they made were high. This is because during the transaction, in this case the purchase or renewals of car insurance, consumers need to pay the premium cost, fill out the document, etc. Therefore, these monetary and non-monetary sacrifices which have happened very recently may well still stay in the consumers' memory. However, when the transaction happened a long time in the past and consumers were asked about their perceived value, the sacrifices made by these consumers may fade away. The implication is that, if customer perceived value is affected by the time of transaction, as a consequence, it will impact on its relationship with behavioral intentions.

Taking further the study by Choi et al. (2004), the positive direct link between value and behavioral intentions is dependent on when the consumers are asked about their perceived value toward the product or service. As mention earlier, Choi et al.'s study was undertaken when consumers were still in the process of receiving the service, at which point it is arguable whether the consumers may articulate their behavioral intentions in terms of repurchase and carrying out word-of-mouth communication very well. Therefore, their model of study indicates a positive direct link between customer value and behavioral intentions. Meanwhile, in the present study, consumers were asked about their perceptions toward car insurance after they purchased or renewed their car insurance. Thus, it makes sense that consumers may not express very well their future intentions to repurchase and to do word-ofmouth communication. Hence, there is no direct positive link between customer value and behavioral intentions. This is because the consumers may put out of their mind about the sacrifices they have made which impact on their perceived value and the articulation of future behavior.

Moreover, the finding of this study is in agreement with the study by Lam et al. (2004) who highlight the mediating role of satisfaction in the impact on customer loyalty. More precisely, they suggest that customer satisfaction mediates totally the relationship between customer value and word-of-mouth communication. Meanwhile, satisfaction mediates partially the relationship between customer value and repurchase intention. Similar to this present study, the study of Lam et al. was conducted after the consumers made the transaction. In the case of Lam et al., consumers had used the courier services offered by DPS. From here, it can be 
Gadjah Mada International Journal of Business, September-December 2005, Vol. 7, No. 3

noticed that when the consumers are being asked about their value perception after the transaction was made (i.e. there is time difference/duration between transaction and data collection), they may not clearly express or be sure about their future behavior. Hence, there is no direct link between customer value and behavioral intentions. In other words, the relationship between customer value and behavioral intentions is mediated by satisfaction.

From the above, it is interesting to reveal further, what factors affect customer perceived value, and hence impact on a direct positive relationship between value and behavioral intentions. And further still, what factors affect the mediating role of customer satisfaction on the impact of customer value on behavioral intentions. These factors may include type of product, the duration between the transaction of purchase and the time of filling the questionnaire, and others. These factors need to be investigated for further research.

\section{Conclusions}

This study confirms previous studies which support the "value $\varnothing$ satisfaction" model (e.g. Choi et al. 2004; Cronin, Brady, and Hult 2000; Fornell et al. 1996; Lam et al. 2004; McDougall and Levesque 2000; Patterson and Spreng 1997; Yang and Peterson 2004).
Hence, the finding of this study contradicts with the scholars who support the "satisfaction $\rightarrow$ value" model (e.g. Bolton and Drew 1991; Petrick et al. 2001). This study also confirms that customer satisfaction mediates the relationship between customer value and behavioral intentions (e.g. Fornell et al. 1996; Lam et al. 2004; McDougall and Levesque 2000; Patterson and Spreng 1997). Hence, the finding of this study contradicts those scholars who support the positive direct link between customer value and behavioral intentions (e.g. Chang and Wildt 1994; Hartline and Jones 1996; Cronin et al. 1997). Further to this, the contribution of this study to the body of customer value literature is enhanced by the finding that perceived value is affected by the time interval between data collection and the transaction of the purchase. Consumers who are asked their perception of value during the process of service or product delivery, or recently after the purchase will have a different perception of value from those consumers for whom there was a considerable time lapse between the purchase and being questioned about their perception of value. As a result, this affects the value relationship with satisfaction and future behavior. This finding suggests that future research in the field of customer value should take into consideration the time of data collection and when the consumers made the purchase. 
Wahyuningsih-The Relationships among Customer Value, Satisfaction, and...

\section{References}

Anderson, E. W., and M. W. Sullivan. 1993. The antecedents and consequences of customer satisfaction for firms. Marketing Science 12 (2): 125-143.

Anderson, J. C., and D. W. Gerbing. 1988. Structural equation modeling in practice: A review and recommended two-step approach. Psychological Bulletin 103 (3): 411423.

C. Jain, and P. K. Chintagunta. 1993. Customer value assessment in business markets. Journal of Business-to-Business Marketing 1: 3-29.

Arbuckle, J. L. 1999. AMOS 4.0 User's Guide. Chicago, The USA: SmallWaters Co.

Bansal, H. S., and P. A. Voyer. 2000. Word-of-mouth processes within a services purchase decision context. Journal of Service Research 3 (2): 166-177.

Barlow, J., and D. Maul. 2000. Emotional Value: Creating Strong Bonds with Your Customers. San Fransisco: Berrett-Koehler.

Bollen, K. A. 1989. Structural Equations with Latent Variables. New York: John Wiley \& Sons.

Bolton, R. N., and J. H. Drew. 1991. A multistage model of customers' assessments of service quality and value. Journal of Consumer Research 17 (4): 375-384.

, P. K. Kannan, and M. D. Bramlett. 2000. Implications of loyalty program membership and service experiences for customer retention and value. Journal of The Academy of Marketing Science 28 (1): 95-108.

Browne, M. W., and R. Cudeck. 1993. Alternative ways of assessing model fit. In Testing Structural Equation Models. edited by Kenneth A. Bollen and J. S. Long. Newbury Park, CA: Sage.

Byrne, B. M. 1998. Structural Equation Modelling with LISREL, PRELIS, and SIMPLIS: Basic Concepts, Applications, and Programming. Mahwah, New Jersey: Lawrence Erlbaum Associates.

Caruana, A., A. Money, and P. Berthon. 2000. Service quality and satisfaction - The moderating role of value. European Journal of Marketing 34 (11/12): 1338-1352.

Chan, L. K., Y. V. Hui, H. P. Lo, S. K. Tse, G. K.F. Tso, and M. L. Wu. 2003. Consumer satisfaction index: New practice and findings. European Journal of Marketing 37 (5/6): 872-911.

Chang, T-Z., and A. R. Wildt. 1994. Price, product information, and purchase intention: An empirical study. Journal of the Academy of Marketing Science 22 (1): 16-27.

Choi, K-S., W-H. Cho, S. Lee, H. Lee, and C. Kim. 2004. The relationships among quality, value, satisfaction and behavioral intention in health care provider choice: A south Korean study. Journal of Business Research 57: 913-921.

Churchill, G. A., and C. Surprenant. 1982. An investigation into the determinants of customer satisfaction. Journal of Marketing Research 19 (November): 491-504.

Cronin, J., M. Brady, R. Brand, R. Hightower, and D. Shemwell. 1997. A cross-sectional test of the effect and conceptualization of service value. The Journal of Service Marketing 11 (6): 357-391. 
Gadjah Mada International Journal of Business, September-December 2005, Vol. 7, No. 3

, M. Brady, and T. M. Hult. 2000. Assessing the effects of quality, value, and customer satisfaction on consumer behavioral intentions in service environments. Journal of Retailing 76 (2): 193-218.

Day, R. L. 1984. Modelling choices among alternative responses to dissatisfaction. Advances in Consumer Research 11 (edited by William D. Perreault). Atlanta, GA: Association for Consumer Research): 496-499.

Eggert, A., and W, Ulaga. 2002. Customer perceived value: A substitute for satisfaction in business markets? Journal of Business and Industrial Marketing 17 (2/3): 107 118.

Ennew, C., A. Banerjee, and D. Li. 2000. Managing word of mouth communication: Empirical evidence from India. International Journal of Bank Marketing 18(2): 7583.

Fornell, C. 1992. A national customer satisfaction barometer: The Swedish experience. Journal of Marketing 56 (1): 6-21.

, M. D. Johnson, E. Anderson, J. Cha, and B. E. Bryant. 1996. The American customer satisfaction index: Nature, purpose, and findings. Journal of Marketing 60 (October): 7-18.

Flint, D. J., R. B. Woodruff, and S. F. Gardial. 2002. Exploring the phenomenon of customers' desired value change in a business-to-business context. Journal of Marketing 66 (October): p. 102-117.

Gabbott, M. 2004. Introduction to Marketing: A Value Exchange Approach. New South Wales, Australia: Prentice Hall.

Gabler, J., and M. Y. Jones. 2000. Behavior and behavioral intentions in a retail setting. ANZMAC 2000 Visionary Marketing for the 21st Century: Facing the Challenge: 377-382.

Gale, B. T. 1994. Managing Customer Value. New york, The USA: The Free Press.

Giese, J. L., and J. A. Cote. 2002. Defining consumer satisfaction. Academy of Marketing Science Review 2000 (1): 1-24.

Gremler, D. D., K. P. Gwinner, and S. W. Brown. 2001. Generating positive word-ofmouth communication through customer-employee relationships. International Journal of Service Industry Management 12 (1): 44-59.

Grewal, D., K. B. Monroe, and R. Krishnan. 1998. The effects of price-comparison advertising on buyers' perceptions of acquisition value, transaction value, and behavioral intentions. Journal of Marketing 62 (April): 46-59.

Grisaffe, D. B., and A. Kumar. 1998. Antecedents and consequences of customer value: Testing an expanded framework. Marketing Science Institute 98-107: 1-32.

Gross, I. 1997. Evolution in customer value: The gross perspective. In Customer Value: Moving Forward - Back to Basics. Edited by B. Donath (ISBM Report No.13).

Harrison-Walker, L. J. 2001. The measurement of word-of-mouth communication and an investigation of service quality and customer commitment as potential antecedents. Journal of Service Research 4 (1): 60-77. 
Wahyuningsih-The Relationships among Customer Value, Satisfaction, and...

Hartline, M. D., and K. C. Jones. 1996. Employee performance cues in a hotel service environment: Influence on perceived service quality, value, and word-of-mouth intentions. Journal of Business Research 35 (3): 207-215.

Hellier, P. K., G. Geursen, R. A. Carr, and J. A. Rickard. 2003. Customer repurchase intention: A general structural equation model. European Journal of Marketing 37 (11/12): 1762-1800.

Holbrook, M. B. 1999. Consumer Value: A Framework for Analysis and Research. New York: Routledge.

Huber, F., A. Herrmann, and R. E. Morgan. 2001. Gaining competitive advantage through customer value oriented management. Journal of Consumer Marketing 18 (1): 41-53.

Jones, T. O., and W. E. Sasser. 1995. Why satisfied customers defect. Harvard Business Review 73 (6): 88-99.

Johnson, M .P., E. W. Anderson, and C. Fornell. 1995. Rational and adaptive performance expectations in a customer satisfaction framework. Journal of Consumer Research 21 (March): 695-707.

Lam, S. Y., S. Venkatesh, M. K. Erramilli, and B. Murthy. 2004. Customer value, satisfaction, loyalty, and switching costs: An illustration from a business-tobusiness service context. Journal of the Academy of Marketing Science 32 (3): 293311.

Mangold, W. G., F. Miller, and G. R. Brockway. 1999. Word-of-mouth communication in the service marketplace. Journal of Services Marketing 13 (1): 73-89.

McDougall, G. H.G., and T. Levesque. 2000. Customer satisfaction with services: Putting perceived value into the equation. Journal of Services Marketing 14 (5): 392-410.

McQuitty, S., A. Finn, and J. B. Wiley. 2000. Systematically varying consumer satisfaction and its implication for product choice. Academy of Marketing Science Review. http://www.amsreview.org/theory/mcquitty10-00.html.

McNaughton, R. B., P. Osborne, and B. C. Imrie. 2002. Market-oriented value creation in service firms. European Journal of Marketing 36 (9/10): 990-1002.

Monroe, K. B. 1990. Pricing: Making Profitable Decisions. New York, The USA: McGraw-Hill.

Morwitz, V. G., and D. Schmittlein. 1992. Using segmentation to improve sales forecast based on purchase intention. Journal of Marketing Research 29 (November): 391406.

Murray, K. B. 1991. A test of services marketing theory: Consumer information acquition activities. Journal of Marketing 55 (1): 10-25.

Naumann, E., and K. Giel. 1995. Customer Satisfaction Measurement and Management: Using the Voice of the Customer. Cincinnati, Ohio: Thomson Executive Press.

Neal, William D. 1999. Satisfaction is nice, but value drives loyalty. Marketing Research (Spring): 21-23. 
Gadjah Mada International Journal of Business, September-December 2005, Vol. 7, No. 3

Parasuraman, A. 1997. Reflections on gaining competitive advantage through customer value. Journal of the Academy of Marketing Science 25 (2): 154-161.

Reichheld, F. 1996. The Loyalty Effect: The hidden Force Behind Growth, Profits, and Lasting Value. Boston: Harvard Business School Press.

Oliver, R. L. 1980. A cognitive model of the antecedents and consequences of satisfaction decisions. Journal of Marketing Research 17 (September): 46-49.

1993. Cognitive, affective, and attribute bases of the satisfaction. Journal of Consumer Research 20 (3): 451-466.

Patterson, P. G. and R. A. Spreng. 1997. Modelling the relationship between perceived value, satisfaction and repurchase intentions in a business-to-business, services context: An empirical examination. International Journal of Service Industry Management 8 (5): 414-434.

Petrick, J. F., D. D. Morais, and W. Norman. 2001. An examination of the determinants of entertainment vacationers' intentions to revisit. Journal of Travel Research 40 (August): 41-48.

Petrick, J. F. 2002. Development of a multi-dimensional scale for measuring the perceived value of a service. Journal of Leisure Research 34 (2): 119-134.

Porter, M. E. 1985. Competitive Advantage: Creating and Sustaining Superior Performance. New York: Free Press.

Sheth, J. N., B. I. Newman, and B. L. Gross. 1991. Consumption Values and Market Choice. Cincinati, Ohio: South Western Publishing.

Sheth, J. N., B. Mittal, and B. I. Newman. 1999. Customer Behavior: Consumer Behavior and Beyond. The USA: The Dryden Press

Slater, S., and J.C. Narver. 1994. Does competitive environment moderate the market orientation-performance relationships? Journal of Marketing 58 (1): 46-55.

Spreng, R. A., G. Harrell, and R. D. Mackoy. 1995. Service recovery: Impact on satisfaction and intentions. Journal of Services Marketing 9 (1): 15-23.

Sweeney, J. C., and G. N. Soutar. 2001. Consumer perceived value: The development of a multiple item scale. Journal of Retailing 77 (2): 203-220.

, G. N. Soutar, and L. W. Johnson. 1999. The role of perceived risk in the quality-value relationship: A study in a retail environment, Journal of Retailing 75 (1): 77-105.

Wang, Y., H. Po Lo, R. Chi, and Y. Yang. 2004. An integrated framework for customer value and customer-relationship-management performance: A customer-based perspective from China. Managing Service Quality 14 (2/3): 169-182.

Weiner, B. 1986. An Attribution Theory of Motivation and Emotion. New York: Springer-Verlag.

Weinstein, A. 1998. Customer value: A new paradigm for marketing management. Advances in Business Studies 6 (10): 89-97.

Westbrook, R. A. 1987. Product/consumption-based affective responses and postpurchase processes. Journal of Marketing Research 24 (3): 258-270. 
Wahyuningsih-The Relationships among Customer Value, Satisfaction, and...

, and R. L. Oliver. 1991. The dimensionality of consumption emotion patterns and consumer satisfaction. Journal of Consumer Research 18 (June): 84-91.

Wirtz, J., and J. E.G. Bateson. 1999. Introducing uncertain performance expectations in satisfaction models for services. International Journal of Service Industry Management 10 (1): 82-99.

and P. Chew. 2002. The effects of incentives, deal proneness, satisfaction and tie strength on word-of-mouth behavior. International Journal of Service Industry Management 13 (2): 141-162.

Woodruff, R. B. 1997. Customer value: The next source for competitive advantage. Journal of the Academy of Marketing Science 25 (2): 139-153.

E. R. Cadotte, and R. L. Jenkins. 1983. Modeling consumer satisfaction processes using experience-based norms. Journal of Marketing Research 20 (August): 296-304.

and S. F. Gardial. 1996. Know Your Customer: New Approaches to Understanding Customer Value and Satisfaction. Cambridge, The USA: Blackwell Publishers.

Yang, Z., and R. T. Peterson. 2004. Customer perceived value, satisfaction, and loyalty: The role of switching costs. Psychology and Marketing 21 (10) (October): 799-822.

Yi, J. 1990. A critical review of consumer satisfaction. In Review of Marketing edited by Valarie.A. Zeithaml. Chicago: American Marketing Association.

Zeithaml, V. A., L. Berry, and A. Parasuraman. 1996. The behavioral consequences of service quality. Journal of Marketing 60 (April): 31-46.

Zikmund, W. G. 1994. Exploring Marketing Research (5 ${ }^{\text {th }}$ Ed.). The Dryden Press, The USA: 371 . 